science in the School may be reckoned to commence from this date. On Hall's retirement in 1869 , he was succeeded by Henry Durham, who had joined the staff with Isaac Scarf in the previous year. These two gave yeoman service to the School and did not retire until 1910 and 1919 respectively. They taught throughout a period when science underwent revolutionary changes, and the development of science teaching in the School kept pace accordingly. In 1869 Dr. Abbott, the headmaster, introduced science throughout the curriculum, and his successor, Mr. Pollard, founded the science side in 1892 ; the jubilee of the teaching of science was marked in 1897 with the Hall Memorial Scholarship. Durham was succeeded by G. C. Donington as senior science master, but the latter died soon afterwards and was replaced by G. H. J. Adlam, who died recently. In 1927 the new science laboratories were opened by the Lord Mayor of London, and they consisted of advanced and elementary laboratories, a chemistry lecture room, a balance room and a room for the science staff; soon afterwards, in 1929, a biological laboratory was completed. A further biological laboratory and a museum were added in 1937, and in 1946 the balance room was converted to an advanced physics lecture room.

The centenary of the teaching of science fell in 1947 and was celebrated at the Great Hall of the School on the afternoon of November 6 this year. There was a large gathering of officials of the Corporation, the Schools Committee, the School staff, parents, and past and present pupils, and the chief guest was the Lord Mayor and Lady Mayoress of London. The headmaster, Mr. F. R. Dale, reminded his audience that, on inspecting some laboratories, a predecessor of his, Dr. Abbott, had once said, "You and I know that this is not education". The Lord Mayor made a short address, and was followed by Sir Harold Scott, lately director of the Bureau of Hygiene and Tropical Diseases, who was himself an old pupil of the School. Various demonstrations and exhibits had been arranged in the School laboratories.

\section{Chemistry and Chemical Technology at University College, Dublin}

Mr. Michael Tiernex, president of University College, Dublin, recently opened in the College a new laboratory for the teaching of chemical technology. Prof. T. S. Wheeler explained that this new laboratory would be known as the Nolan Laboratory in remembrance of the late Prof. T. J. Nolan, whose untimely death had prevented him putting into operation plans he had formulated for the teaching of chemical technology in the College. Mr. Tierney also opened a laboratory for final years honours chemistry, which will be known as the Ryan Laboratory, in remem. brance of the late Prof. Hugh Ryan, the first professor of chemistry in University College, Dublin.

\section{Bioluminescence}

IN connexion with Dr. V. B. Wigglesworth's article on bioluminescence in Nature of September 11 , p. 423, Mr. K. B. Williamson, c/o Manson House, 26 Portland Place, London, W.1, has recalled observations made by him while he was malaria research officer in Malaya some years ago. A dytiscid beetle which fell about three feet off the laboratory bench on to the floor of the old Malaria Bureau, Kuala Lumpur, displayed a unique type of bioluminescence. The beetle appeared to emit bright flashes of white light, three or four at a time, from its eyes.
The fluorescent type of bioluminescence is invisible even in weak light ; but these flashes were conspicuous in competition with the light from a fairly bright electric bulb on the laboratory bench. The groups of flashes were repeated several times within half an hour, when the beetle was again dropped from the same height; but never afterwards, when the dropping was repeated during the subsequent months it was kept alive. In sharp contrast to another Dytiscus, it failed to capture any mosquito larvæ or pupæ during these months, and it not improbably died of starvation; and may have been blinded by destruction of retinal pigment and damage to the cells producing it. Mr. Williamson tentatively suggests that the flashes from the beetle's eyes were caused by reversal of the normal process of vision, energy in the form of light having been emitted instead of being absorbed by retinal pigment, as the result of intermittent outwardly directed nervous impulses, due to shock.

\section{Earthquakes during July and August}

DuRING July, nineteen strong earthquakes occurred in various parts of the world, the strongest being of instrumental scale $7 t$ and occurring off the southwest coast of Peru on July 20. It had a depth of focus of $100 \mathrm{~km}$. Two earthquakes on July 16 radiating from a focus having an epicentre near the coast of Guatemala and having strengths $6 \frac{1}{4}$ and 68 were felt in Guatemala and San Salvador. The only earthquakes to do damage during the month occurred on July 20, damaging buildings on Coiba Island.

During August, twenty-four strong earthquakes occurred in various parts of the world. The strongest occurred on August 25 in the Salta Province of Argentina and attained scale $7 \frac{1}{2}$. During the month there was also rather more activity than usual along the south European seismic zone, earthquakes occurring on August 10 in the region of Alasehir in Turkey; on August 12,13 and 15 near Oporto in Portugal; on August 18 near Sivrice in Turkey, and at Apulia in south Italy; on August 21, destructive at Orda Nova in south Italy; on August 22 in Portugal and Italy; and on August 27 in the region of Skadar, Albania. On August 30 there was also a repetition of an earthquake which occurred on July 8 in a rather unusual area-near Jan Mayen Island.

Group reports have been received from the United States Coast and Geodetic Survey, the central station at Strasbourg, the Jesuit seismological central station at St. Louis, United States, and individual station reports have been received from Beograd, Cleveland (Ohio), De Bilt, Durham, Kew, Stuttgart, Toledo and Uccle.

\section{Polytetrafluoroethylene}

THE outstanding stability of fluorinated hydrocarbons has been fully exploited in the field of high polymers. The preparation and polymerization of tetrafluoroethylene was described some two years ago (Ind. Eng. Chem., 870; 1946). The polymer (P.T.F.E.) is an excellent dielectric (power factor = 0.0002 over a wide frequency-range) and it is resistant to all common solvents up to $300^{\circ} \mathrm{C}$. Molten alkali metals alone have any appreciable attack. In its strength, however, lies its greatest weakness. Form stability is retained up to $250^{\circ} \mathrm{C}$., and even at higher temperatures there is no true softening; thus moulding and fabrication present major obstacles. Pro. gress in overcoming this difficulty has, however, been made by Messrs. British Mechanical Productions, 